\title{
Pengaruh Kompetensi, Motivasi Kerja dan Kepuasan Kerja terhadap Kinerja Dosen
}

\author{
Hari Wahyuni \\ Fakultas Ekonomi Universitas Merdeka Pasuruan, Indonesia \\ yuniprasetya55@gmail.com
}

\begin{abstract}
The purposes of this study are to determine and analyze the influence of competence, work motivation and job satisfaction on the performance of lecturer at Merdeka University Pasuruan. Data analysis uses a quantitative analysis. Population in this research are all permanent lecturers at Universitas Merdeka Pasuruan as 43 lecturers. Sample taken by census method. The results of research show that: 1) competence has a significant influence on the performance of lecturer, 2) work motivation has a significant influence on the performance of lecturer, 3) job staisfaction has a significant influence on the performance of lecturer, 4) job satisfaction has a dominant effect on lecturer performance.
\end{abstract}

Keywords: Competence, Job Satisfaction, Lecturer Performance, Work Motivation

\section{PENDAHULUAN}

Kinerja dosen adalah faktor yang sangat penting sehingga hal ini merupakan tantangan tersendiri untuk Universitas Merdeka Pasuruan, karena keberhasilan suatu lembaga perguruan tinggi tergantung pada sumber daya manusia yang berkualitas. Dalam menjalankan perannya sebagai seorang dosen dimana ruang lingkup kerja dosen meliputi pendidikan dan pengajaran terhadap peserta didik, kegiatan penelitian, dan pengabdian yang bertujuan memberikan pelayanan dan membantu masyarakat yang membutuhkan bimbingan sesuai dengan bidang ilmu dosen. Selain Tri Dharma Perguruan Tinggi, di Universitas Merdeka Pasuruan dosen juga dapat berperan dalam mensukseskan jalannya proses pendidikan di perguruan tinggi serta ikut berperan pada terlaksananya tata kelola yang mendukung perkembangan dan kemajuan perguruan tinggi. Hal ini karena secara administratif dosen adalah seorang yang mempunyai keahlian dibidang akademik yang diangkat oleh Universitas Merdeka Pasuruan.

"Motivasi adalah sesuatu yang mempengaruhi pada beberapa tahapan perbuatan seorang individu dalam upaya mewujudkan apa yang menjadi tujuanya" (Wibowo,2014:323). Sesuai penelitian Respatiningsih dan Sudirjo (2015) memperlihatkan motivasi mempengaruhi kinerja pengawai secara positif serta signifikan. Motivasi kerja merupakan aspek yang penting mempengaruhi kinerja sebab dengan motivasi kerja yang baik dapat menghasilkan kinerja yang baik serta berkualitas juga.

"Kompetensi merupakan suatu keahlian serta kemampuan yang ada pada diri individu dan didorong oleh tindakan bekerja yang disebabkan kewajiban dalam pekerjaan (Wibowo,2014:110). Sesuai dengan penelitian yang dilakukan Faitullah (2014) dalam penelitian tersebut menyatakan bahwa kompetensi paling dominan mempengaruhi 
kinerja dosen, kompetensi yang diterima oleh dosen semakin berkualitas maka dengan begitu dapat membuat kinerja yang diraih dosen semakin baik. Berdasarkan kompetensi yang dipunyai dosen serta motivasi kerja yang dirasakan oleh dosen bisa membuat seorang dosen untuk meningkatkan kinerjanya.

Kepuasan kerja yang dimiliki dosen adalah penilaian dari perasaan para dosen terhadap pekerjaannya. Seorang dosen bekerja pada Universitas Merdeka Pasuruan untuk memenuhi kebutuhan dan keinginannya supaya bisa menyatu membentuk harapan kerja. Sesuai dengan pendapat Robbins dan Judge “ kepuasan kerja merupakan sesuatu yang dirasakan oleh individu yang memberikan dampak baik terkait hasil kerjanya untuk perbaikan pekerjaanya sesuai cirikhas yang dimilki” (Wibowo, 2014: 132). Menurut penelitian Wijayanti dan Meftahudin (2016) menunjukkan kepuasan kerja mempengaruhi kinerja karyawan secara positif. Keadaan ini berarti kalau, kepuasan kerja semakin baik, dengan begitu dapat membuat kinerja karyawan juga semakin baik. Semakin baik skor kepuasan kerja, maka semakin baik pula kinerja yang diraih karyawan dan demikian pula sebaliknya.

Kinerja adalah suatu tahapan yang diraih para pekerja baik dari segi mutu saat menjalankan pekerjaanya sesuai dengan akuntabilitas yang dibebankan kepadanya (Mangkunegara,2014:67). Penelitian Marliza (2015) menyatakan bahwa kinerja dosen dipengaruhi kepemimpinan, dan kompetensi serta lingkungan kerja.

Berdasarkan pengamatan di lapangan permasalahan yang ada dalam kinerja dosen di Universitas Merdeka Pasuruan berdasarkan pendidikan dan pengajaran terhadap peserta didik, penelitian yang dilaksanakan dosen serta pengabdian dosen pada warga masyarakat maka kinerja dosen masih belum optimal dikarenakan beberapa dosen masih belum memiliki jabatan fungsional dan dari data yang ada di Universitas Merdeka Pasuruan masih banyak dosen yang belum melakukan penelitian.
Berdasarkan kinerja dosen Universitas Merdeka Pasuruan yang belum optimal dan menjawab persepsi kinerja individu dan fakta-fakta yang mempengaruhi, maka dilakukan penelitian ini untuk dapat mengkaji lebih mendalam terkait kompetensi, motivasi kerja dan kepuasan kerja serta kinerja dosen di Universitas Merdeka Pasuruan.

Tabel 1. Daftar Kinerja Penelitian Dosen UNMER Pasuruan

\begin{tabular}{lcccc}
\hline & 2014 & 2015 & 2016 & 2017 \\
\hline Hibah bersaing & - & - & - & 1 \\
Dosen Mandiri & 6 & 2 & 3 & 2 \\
$\begin{array}{l}\text { Dosen } \\
\text { Kelompok }\end{array}$ & 2 & 1 & 7 & 5 \\
Hibah Pemprov & - & - & - & - \\
Jumlah & 8 & 3 & 10 & 8 \\
\hline
\end{tabular}

Sumber : LPPM Unmer Pasuruan

Berdasarkan tabel 1 diatas menunjukkan bahwa penelitian dosen di Universitas Merdeka Pasuruan masih jauh dari yang diharapkan. Semua ini dikarenakan jumlah penelitian yang dihasilkan dosen dibanding jumlah dosen, masih rendah. Namun disisi pengabdian masyarakat menunjukkan kinerja yang meningkat dari tahun ke tahun sebagaimana tabel 2 berikut :

Tabel 2. Pengabdian Kepada Masyarakat Dosen UNMER Pasuruan

\begin{tabular}{ccccc}
\hline Jenis Pengabdian & 2014 & 2015 & 2016 & 2017 \\
\hline KKN & 11 & 13 & 15 & 17 \\
BAPEMAS & - & - & 1 & 3 \\
Lain - Lain & - & - & 3 & 7 \\
Jumlah & 11 & 13 & 19 & 27
\end{tabular}

Sumber : LPPM Unmer Pasuruan

\section{Pengaruh Kompetensi Terhadap Kinerja}

"Kompetensi adalah ketrampilan, keahlian serta sikap yang ada pada diri seseorang dalam mengemban kewajiban sesuai dengan perfom yang ditetapkan" (Gaol, 2014:503). Menurut Wibowo 
(2014:110) menjelaskan bahwa "kompetensi adalah kesanggupan keterampilan, pengetahuan serta adanya semangat dalam bekerja untuk mengerjakan pekerjaan sesuai beban kerja yang menjadi tanggungjawabnya”. Dosen yang memiliki maka kinerja yang dihasilkan menjadi lebih baik. Maka dapat disimpulkan bahwa kompetensi dosen adalah kesanggupan/kecakapan seorang dosen mengerjakan pekerjaan yang dibebankan kepadanya sesuai dengan keahlian, ketrampilan serta didukung sikap kerja.

Berdasarkan Peraturan Menteri Pendidikan Nasional Republik Indonesia No. 16 Tahun 2007 yang berkaitan dengan standar kualifikasi akademik serta kompetensi guru dan dosen disebutkan bahwa seorang guru dan dosen harus memiliki empat kompetensi sesuai kewajiban untuk menjalankan tugasnya sebagai tenaga pendidik. Keempat kompetensi tersebut meliputi kompetensi pedagogik, profesional, kepribadian dan sosial.

Kompetensi pedagogik terdiri dari kemampuan guru dan dosen memahami siswa/mahasiswa, mengimplementasikan dan menyusun materi yang diajarkan, mengevaluasi hasil belajar, mengarahkan siswa maupun mahasiswa menerapkan berbagai kemampuannya. Kompetensi Profesional terdiri dari memahami materi yang akan diajarkan atau menguasai materi konseptual, yang terdiri dari memahami bahan kurikulum mata pelajaran di sekolah dan subtansi keilmuan yang menaungi materinnya, serta penguasaaan terhadap struktur dan metodenya. Kompetensi kepribadian terdiri dari kemampuan seorang pendidik yang mencerminkan kepribadian yang bagus, konsisten, bijaksana, bisa menjadi tauladan, dan kharismatik, bisa memberikan contoh yan baik bagi peserta didik, dan berjiwa religius. Kompetensi sosial meliputi keahlian pendidik terkait kemampuan berkomunikasi serta menjalin kedekatan dengan baik terhadap peserta didik, sesama pendidik, tenaga kependidikan, orang tua/wali peserta didik, serta warga masyarakat.
Beberapa penelitian terdahulu telah mengarahkan bahwa kompetensi mempengaruhi kinerja individu diantaranya adalah penelitian Faitullah (2014) dan Marliza (2015) yang menghasilkan hasil yang sama bahwa kompetensi mempengaruhi kinerja dosen.

\section{Pengaruh Motivasi Terhadap Kinerja}

Dalam Bangun (2012:316) terdapat jenjang kebutuhan individu menurut Abraham Maslow adalah: 1) Faali/Fisiologis adalah sesuatu yang paling utama dibutuhkan oleh seorang individu. Individu saat menjalani hidupnya lebih memfokuskan kebutuhan faali/fisiologis, faali merupakan sesuatu yang paling utama, kebutuhan faali terdiri dari lapar, haus, peristirahatan, biologis, dan istirahat; 2) Keamanan akan tercapai jika dalam kehidupannya seseorang sudah mampu memenuhi faali/fisiologis dimana yang termasuk keamanan pada organisasi yaitu terdapat jaminan keamanan saat bekerja misalnya terdapat asuransi untuk para pekerja, tunjangan kesehatan serta tunjangan pensiun; 3) Sosial merupakan urutan atau kasta ketiga, dimana setiap manusia ingin hidup bersama-sama atau membutuhkan bantuan individu lainnya. Sosial meliputi saling mengasihi, menginginkan sesuatu, dihargai, dan pertemanan; 4) Penghargaan merupakan tingkat keempat yang terdiri dari aspek rasa hormat dari dalam diri individu seperti igin dihargai, kebebasan, dan kesuksesan. aspek rasa hormat dari luar diri individu seperti kedudukan, diakui serta diperhatikan; 5) Aktualisasi diri adalah tingkatan paling tinggi/ tingkat kelima dimana dapat tercapai jika empat tingkatan sebelumnya sudah terpenuhi. Aktualisasi diri terdiri dari sasaran yang diharapkan dapat terwujud.

Sesuai penelitian Respatiningsih dan Sudirjo (2015) memperlihatkan bahwa motivasi mempengaruhi kinerja pegawai secara positif dan signifikan. Motivasi kerja merupakan aspek yang penting mempengaruhi kinerja sebab dengan motivasi kerja yang baik dapat menghasilkan kinerja yang baik serta berkualitas juga. 


\section{Pengaruh Kepuasan Kerja dengan Kinerja}

Sesuai pendapat Robbins (2013:312)

"Kepuasan kerja adalah cara pandang universal seorang karyawan akan apa yang dikerjakan, yang menunjukan perbedaan besarnya jumlah imbalan yang didapat serta besarnya jumlah yang diyakini haruslah didapat”. Mangkunegara (2012:117) menyatakan "Kepuasan kerja merupakan rasa puas pada diri pegawai yang berdampak positif maupun tidak yang berhubungan dengan pekerjaanya”. Berdasarkan peryataan tersebut bisa dijelaskan kalau kepuasan kerja merupakan rasa puas pada diri seorang karyawan terkait pekerjaan yang diberikan kepadanya. Penelitian ini menggunakan beberapa indikator-indikator antara lain adalah: 1) gaji, 2) kemakmuran dosen terhadap pekerjaan, 3) perasaan bangga dosen terhadap tempat kerja, 4) apresiasi terhadap hasil kerja dosen, 5) substansial tugas dosen, 6) peluang untuk maju dosen, 7) hak dosen mengatur sistem kerja, 8) tanggapan langsung dosen terhadap tugas.

Menurut Kuswadi (2004:55) dosen yang mendapatkan kepuasan kerja maka kinerja dosen tersebut akan maksimal sampai jangka panjang danmendapatkan hasil yang bermutu yang lebih baik dan lebih produktif, Dosen yang merasa puas akan mencapai kinerja yang semakin meningkat, dapat bekerja lebih langgeng pada suatu organisasi dimana dosen tersebut bekerja, mampu menjalin kerja sama dengan mahasiswa. Menurut penelitian terdahulu yang dilakukan oleh Respatingsih dan Sudirjo (2015) hasilnya menunjukkan bahwa ada pengaruh dari kepuasan kerja terhadap kinerja dosen karena dosen merasakan kepuasan maka kinerja dosen tersebut semakin meningkat dan produktif.

Berdasarkan uraian di atas, maka dapat dirumusakan hipotesis sebagai berikut:

\section{$\mathrm{H}_{1}$ : kompetensi berpengaruh terhadap kinerja dosen di Universitas Merdeka Pasuruan.}

$\mathrm{H}_{2}$ : motivasi berpengaruh terhadap kinerja karyawan di Universitas Merdeka Pasuruan.

$\mathrm{H}_{3}$ : kepuasan kerja organisasi berpengaruh terhadap kinerja karyawan di Universitas Merdeka Pasuruan

\section{METODE}

Rancangan penelitian pada penelitian penulis adalah metode eksplanasi dengan teknik survei guna menganalisis pengaruh kompetensi dosen, motivasi kerja dosen serta kepuasan kerja yang dirasakan dosen terhadap kinerja dosen Univerisitas Merdeka Pasuruan. Penelitian ini dilaksanakan di Universitas Merdeka Pasuruan karena hanya ada satu Universitas yang ada di kota Pasuruan.

\section{Jenis dan Sumber Data}

Pada penelitian ini adapun data yang dipakai merupakan kuantitatif. Serta menggunakan data primer. Selaian sumber data primer juga sumber data sekunder. Sumber data primer pada penelitian ini berasal dari pernyataan responden melalui koesioner yang berkaitan dengan kompetensi, motivasi kerja dankepuasan kerja pada kinerja dosen Universitas Merdeka Pasuruan. Populasi terkait dengan penelitian ini yaitu semua dosen Universitas Merdeka Pasuruan yang memiliki karakteristik dosen tetap, yang berjumlah 43 dosen. Pengambilan sampel dengan cara memakai metode sensus sebab semua populasi dijadikan sampel penelitian.

\section{Teknik Analisis Data}

Teknik analisis data yang digunakan adalah analisa kuantitatif dengan Metode Regresi Linear Berganda. Regresi linier Berganda guna mendeteksi apakah kompetensi $\left(\mathrm{X}_{1}\right)$, motivasi kerja $\left(\mathrm{X}_{2}\right)$, kepuasan kerja $\left(\mathrm{X}_{3}\right)$ mempengaruhi kinerja dosen (Y) jika terdapat perubahan diantara salah satu variabel independen. Adapun persamaan regresi linier berganda yang digunakan adalah :

$$
\mathrm{Y}=\mathrm{a}+\mathrm{b}_{1} \mathrm{X}_{1}+\mathrm{b}_{2} \mathrm{X}_{2}+\mathrm{b}_{3} \mathrm{X}_{3}+\mathrm{e}
$$




\section{HASIL DAN PEMBAHASAN Uji Validitas}

Berdasarkan uji validitas dari seluruh item yang diukur menunjukkan adanya korelasi dan lebih besar dari $r_{\text {tabel}}$, dengan membandingkan probabilitas nilai signifikan 2 - tailed. Hasil perhitungan dengan $\alpha=0,05$ semua butir pernyataan mempunyai nilai signifikan 2 - tailed yang lebih kecil dari $\alpha=$ 0,05 maka berdasarkan hasil tersebut terdapat korelasi yang relevan antara nilai dari tiaptiap butir pernyataan item pada nilai total, alat ukur yang dipakai pada penelitian ini dinyatakan valid.

\section{Uji Reliabilitas}

Berdasarkan pengujian reliabilitas dapat dinyatakan bahwa hasil uji menggunakan Alpha Cronbach $>$ dari $\mathrm{r}_{\text {tabel }}$ sehingga semua variabel yang diteliti dinyatakan reliable. dari nilai alpha masing masing variabel diperoleh Alpha Cronbach antara $0,80-0,90$, semua instrumen dinyatakan reliabel dan mempunyai reliabilitas sangat tinggi.

Berdasarkan akumulasi pernyataan responden tentang kompetensi diperoleh skor rata-rata sebesar 4,384 ini artinya bahwa responden setuju kompetensi ditentukan oleh pedagogik, profesional, kepribadian dan sosial. Selanjutnya kepribadian merupakan kompetensi yang utama berupa keadilan dalam memperlakukan mahasiswa, karena nilai rata-ratanya paling besar yaitu 4,465.

Berdasarkan akumulasi pernyataan responden tentang motivasi diperoleh skor rata-rata skor sebesar 3,444 berarti responden menyatakan setuju bahwa insentif yang diberikan lembaga perguruan tinggi sudah adil. Kesimpulan rata-rata responden setuju bahwa kebutuhan fisiologis berkontribusi pada motivasi kerja. Item utama yang berkontribusi di kebutuhan fisiologis adalah tunjangan yang diterima dari lembaga perguruan tinggi sudah layak.

Sedangkan untuk akumulasi pernyataan responden tentang kepuasan kerja diperoleh skor rata - rata 3,863 ini berarti bahwa responden setuju kepuasan kerja ditentukan oleh bayaran/upah, kemakmuran dosen terhadap pekerjaan, rasa bangga dosen terhadap tempat kerjanya, apresiasi terhadap hasil kerja dosen, substansi tugas dosen, peluang dosen untuk maju, hak dosen mengatur sistem kerja, dan tanggapan langsung dosen terhadap tugas. Selanjutnya peluang dosen untuk maju merupakan yang utama mendukung kepuasan kerja melalui lembaga memberi kesempatan untuk mengikuti pelatihan karena nilainya paling besar yaitu 4,122.

Berdasarkan akumulasi pernyataan responden tentang kinerja dosen diperoleh skor rata-rata 4,067 ini berarti bahwa responden setuju kinerja dosen ditentukan oleh pendidikan yang dilakukan dosen terhadap peseta didik serta pengajaran, penelitian yang dilakukan dosen dan pengabdian yang dilakukan dosen kepada masyarakat Selanjutnya pendidikan yang dilakukan dosen terhadap peseta didik serta pengajaran merupakan yang utama mendukung kinerja dosen melalui penggunakan metode pembelajaran yang mampu meningkatkan pengetahuan wawasan mahasiswa, karena nilainya paling besar yaitu 4,236.

\section{Uji Asumsi Klasik}

Berdasarkan hasil uji multikolineritas yang telah dilakukan pada tabel 3 bisa diamati kalau skor VIF kompetensi, motivasi kerja dan kepuasan kerja adalah kurang dari 10, sehingga dapat dikatakan tidak terjadi gejala multikolineritas. dengan tolerance tidak kurang dari 0,1 dengan begitu dapat dinyatakan terbebas dari gejala multikolineritas. Hal ini membuktikan bahwa tidak adanya kemiripan antara variabel bebas yang digunakan, sehingga diharapkan tidak ada masalah dalam pengambilan kesimpulan.

Tabel 3. Hasil Uji Multikolineritas

\begin{tabular}{lcc}
\hline \multirow{2}{*}{ Model } & \multicolumn{2}{c}{ Collinearity Statistics } \\
\cline { 2 - 3 } & Tolerence & VIF \\
\hline Kompetensi &, 873 & 1,145 \\
Motivasi Kerja &, 993 & 1,007 \\
Kepuasan Kerja &, 871 & 1,148 \\
\hline
\end{tabular}

Sumber : data diolah 
Sesuai dengan uji autokorelasi yang telah dilakukan diperoleh skor kritis $\mathrm{d}_{\mathrm{L}}=$ 1,366 dan $\mathrm{d}_{\mathrm{U}}=1,663$. Dari hasil olah data yang dilakukan diperoleh nilai Durbin Watson (DW) adalah 1,701. Ketentuan uji Durbin Watson (DW) mensyaratkan $\mathrm{d}_{\mathrm{u}}<\mathrm{dw}$ $<4-$ du; yaitu 1,663 < 1,701 < 4 - 1,769 atau $1,663<1,701<2,337$. Hasil uji Durbin Watson (DW) tersebut menunjukkan tidak terjadi autokorelasi, selanjutnya data bisa dianalisis ketahap berikutnya karena terbebas dari autokorelasi.

Berdasarkan hasil yang diperoleh pada regresi linier berganda asumsi homogenitas terpenuhi. Semua ini menyatakan kalau regresi bisa dilanjutkan pada penelitian, sebab regresi linier berganda terjadi kesamaan residu terhadap satu waktu pengamatan dengan waktu pengamatan lainnya. Kelayakan dalam hal ini regresi dapat digunakan untuk memperkirakan kinerja dosen dengan memasukkan kompetensi, motivasi kerja yang diterima dosen serta kepuasan kerja yang dirasakan dosen.

Hasil uji normalitas dengan alat uji yang dipakai dengan memakai P-Plot menyatakan kalau hasil penelitian berada tersebar disekitar garis diagonal dimana data mengarah searah garis diagonal, maka dengan begitu hasilnya sudah terbagi secara normal dan regresi linier berganda pada penelitian ini menyempurnakan asumsi normalitas.

\section{Uji Regresi Linier Berganda}

Tabel 4. Rekapitulasi Analisis Regresi Linier Berganda

\begin{tabular}{lcccc}
\hline \multirow{1}{*}{ Model } & $\begin{array}{c}\text { Standardized } \\
\text { Coefficients }\end{array}$ & $\mathrm{t}$ & Sig. \\
\cline { 2 - 3 } & \multicolumn{2}{c}{ Beta } & & \\
\hline Constant & $-2,029$ & $-2,699$ &, 010 \\
Kompetensi &, 256 & 2,535 &, 015 \\
Motivasi Kerja &, 414 & & 4,368 &, 000 \\
Kepuasan Kerja &, 576 & 5,687 &, 000 \\
Keterangan : & & & \\
$\mathrm{T}_{\text {table }}$ & 2,022 & & \\
\hline
\end{tabular}

Sumber: data diolah
Berdasarkan analisis regresi linier berganda pada tabel 3 diatas dapat dibuat persamaan regresi seperti berikut ini :

$Y=-2,029+0,256 X_{1}+0,414 X_{2}+0,576 X_{3}$

Hasil analisis regresi linier berganda pada tabel 3 menunjukkan konstanta sebesar -2,029 bermakna bahwa jika dosen tidak memiliki kompetensi, tidak termotivasi dan tidak memperoleh kepuasan kerja maka kinerja dosen Universitas Merdeka Pasuruan akan menurun. Kompetensi mempunyai nilai koefisien regresi (Beta) 0,256 yang berarti kompetensi mempengaruhi kinerja dosen, artinya setiap kenaikan 1\% pada kompetensi akan meningkatkan kinerja dosen sebesar 25,6 \% dan sebaliknya jika terjadi penurunan kompetensi $1 \%$ maka akan menurunkan kinerja dosen di Universitas Merdeka Pasuruan sebesar 25,6\%.

Motivasi kerja memiliki skor koefisien regresi (Beta) 0,414 maka bisa dinyatakan motivasi kerja mempengaruhi kinerja dosen, dengan demikian jika terjadi kenaikan $1 \%$ pada motivasi kerja bisa meningkatkan kinerja dosen sebesar 41,4 \% serta begitu sebaliknya jika terjadi penurunan motivasi kerja 1\% maka akan menurunkan kinerja dosen di Universitas Merdeka Pasuruan sebesar $41,4 \%$.

Kepuasan kerja mempunyai skor koefisien regresi (Beta) 0,576 yang menyatakan kepuasan kerja mempengaruhi kinerja dosen, dengan demikian jika terjadi kenaikan tiap 1\% pada kepuasan kerja akan meningkatkan kinerja dosen sebesar 57,6\% dan sebaliknya jika terjadi penurunan kepuasan kerja 1\% maka akan menurunkan kinerja dosen di Universitas Merdeka Pasuruan sebesar 57,6\%.

Koefisien determinasi yang dihasilkan disini sebanyak 0,625 atau 62,5\% untuk medeteksi seberapa besar hubungan dari kompetensi yang dimiliki, motivasi kerja yang diterima dosen, kepuasan kerja yang dirasakan dosen pada kinerja dosen. Skor koefisien determinasi diatas mengandung makna bahwa kompetensi yang dimilki, motivasi kerja yang diterima dosen, kepuasan 
kerja yang dirasakan dosen mempengaruhi 62,5\% pada kinerja dosen, serta selebihnya yaitu $37,5 \%$ berasal dari variabel lain yang bukan diteliti.

Skor korelasi berganda R berdasarkan analisis yang dilakukan yaitu sebanyak 0,807 . Skor dimaksud menggambarkan kalau terdapat hubungan antara kompetensi yang dimiliki dosen, motivasi kerja yang diterima serta kepuasan kerja yang dirasakan dengan kinerja dosen memiliki keterkaitan yang sangat erat.

\section{Uji Hipotesis}

Hasil perhitungan menunjukkan bahwa probabilitas sebesar siq. F kurang dari 5\% sehingga bisa diartikan kompetensi, motivasi kerja, kepuasan kerja secara bersama-sama mempengaruhi secara signifikan kinerja dosen di Universitas Mereka Pasuruan.

Kompetensi mempunyai skor $t_{\text {hitung }}$ yaitu 2,535 dengan probabilitasnya yaitu 0,015 . dikarenakan $t_{\text {hitung }}$ lebih besar dari $t_{\text {tabel }}$ (2,535 lebih besar dari 2,022) serta tingkat signifikansi $\alpha$ kurang dari 5 \% (0,015 kurang dari 0,05$)$ jadi $\mathrm{H}_{0}$ di tolak, maka kompetensi mempengaruhi secara signifikan kinerja dosen di Universitas Merdeka Pasuruan.

Motivasi Kerja mempunyai skor $t_{\text {hitung }}$ yaitu 4,368 dengan probabilitasnya yaitu 0,000 . dikarenakan $t_{\text {hitung }}$ lebih besar dari $t_{\text {tabel }}$ (4,368 lebih besar dari 2,022) serta tingkat signifikansi $\alpha$ kurang dari $5 \%$ (0,000 kurang dari 0,05$)$ jadi $\mathrm{H}_{0}$ di tolak, maka motivasi kerja mempengaruhi secara signifikan kinerja dosen di Universitas Merdeka Pasuruan.

Kepuasan kerja mempunyai skor $t_{\text {hitung }}$ yaitu 5,687 dengan probabilitasnya yaitu 0,000 . dikarenakan $t_{\text {hitung lebih besar }}$ dari $t_{\text {tabel }}(5,687$ lebih besar dari 2,022) serta tingkat signifikansi $\alpha$ kurang dari $5 \%(0,000$ kurang dari 0 ,05) jadi $\mathrm{H}_{0}$ di tolak, maka kepuasan kerja mempengaruhi secara signifikan kinerja dosen di Universitas Merdeka Pasuruan.

Kepuasan kerja mempunyai koefisien regresi linier (beta) lebih besar yakni 0,576 jika dibandingkan dengan motivasi kerja 0,414 dan kompetensi 0,256. Maka menyatakan bahwa kalau kepuasan kerja yang dirasakan dosen merupakan variabel yang paling dominan mempengaruhi kinerja dosen di Universitas Merdeka Pasuruan.

\section{Pembahasan}

Kompetensi mempengaruhi kinerja dosen di Universitas Merdeka Pasuruan. Hasil penelitian ini sesuai dengan penelitian Faitullah (2014) dan Marliza (2015) yang menghasilkan hasil yang sama bahwa kompetensi mempengaruhi kinerja dosen.

Motivasi kerja mempengaruhi secara signifikan kinerja dosen di Universitas Merdeka Pasuruan. Hasil ini sesuai penelitian Respatiningsih dan Sudirjo (2015) memperlihatkan bahwa motivasi mempengaruhi kinerja pegawai secara positif dan signifikan. Motivasi kerja merupakan aspek yang penting mempengaruhi kinerja sebab dengan motivasi kerja yang baik dapat menghasilkan kinerja yang baik serta berkualitas juga.

Kepuasan kerja mempengaruhi secara signifikan kinerja dosen di Universitas Merdeka Pasuruan. Hasil penelitian ini sesuai dengan penelitian Kuswadi (2004:55) yang menyatakan bahwa dosen yang mendapatkan kepuasan kerja maka kinerja dosen tersebut akan maksimal sampai jangka panjang dan mendapatkan hasil yang bermutu yang lebih baik dan lebih produktif. Hal ini juga sesuai dengan penelitian terdahulu yang dilakukan oleh Respatingsih dan Sudirjo (2015) hasilnya menunjukkan bahwa ada pengaruh dari kepuasan kerja terhadap kinerja dosen karena dosen merasakan kepuasan maka kinerja dosen tersebut semakin meningkat dan produktif. Dalam penelitian ini kepuasan kerja mempunyai pengaruh dominan, hal ini dikarenakan dosen mendapatkan peluang untuk maju dari Universitas Merdeka Pasuruan dimana lembaga memberikan kesempatan kepada para dosen untuk mengikuti berbagai pelatihan. Pelatihan yang diikuti oleh para dosen akan meningkatkan kemampuan dosen pada saat pelaksanaan pengajaran peserta didik serta tahapan pada saat belajar mengajar, penelitian yang dilakukan dosen serta pengabdian para dosen 
pada warga masyarakat sehingga kelengkapan kewajiban dosen untuk menjalankan Tri Dharma Perguruan Tinggi terpenuhi dan meningkatkan kinerja dosen di Universitas Merdeka Pasuruan.

\section{Kesimpulan}

Kompetensi yang dimiliki dosen, motivasi kerja yang diterima, serta kepuasan kerja yang dirasakan dosen menggerakkan kinerja para dosen di Universitas Merdeka Pasuruan, artinya bahwa kinerja dosen di lembaga ini di ditentukan oleh kompetensi serta motivasi kerja telah dimiliki dosen, serta kepuasan kerja yang telah dirasakan dosen.

Diantara variabel kompetensi, motivasi kerja, serta kepuasan kerja dosen yang paling mempengaruhi kinerja dosen Universitas Merdeka Pasuruan adalah kepuasan kerja. Hal ini dikarenakan dosen mendapatkan peluang untuk maju dari Universitas Merdeka Pasuruan yang memberikan kesempatan kepada para dosen untuk mengikuti berbagai pelatihan.

\section{DAFTAR PUSTAKA}

Arikunto,Suharsimi. (2006). Prosedur Penelitian Suatu Pendekatan Praktik. PT. Rineka Cipta. Jakarta.

Bangun, Wilson. (2012). Manajemen Sumber Daya Manusia. PT. Gramedia. Jakarta.

Djaali. (2008). Skala Likert. Pustaka Utama. Jakarta.

Faitullah. (2014). Pengaruh Kompetensi, Motivasi dan Kecerdasan Emosi terhadap Kinerja Dosen di Perguruan Tinggi Swasta Kopertis Wilayah II (Studi Kasus Pada Universitas Binadarma Dan Universitas Tri Dimanti)”. Jurnal manajemen \& bisnis sriwijaya.vol 12 no 4 Desember.

Gaol, CHR. Jimmy L. (2014). Human Capital Manajemen Sumber Daya Manusia. PT. Grasindo. Jakarta.

Hasibuan,Malayu. (2007). Organisasi dan Motivasi. BumiAksara. Jakarta.

Mangkunegara, Anwar Prabu. (2014). Evaluasi Kinerja Sumber Daya
Manusia. PT Refika Aditama,Cet. Ke7. Bandung.

Marliza, Yayuk. (2015). "Pengaruh

Kepemimpinan, Motivasi dan

Kompetensi, Serta Lingkungan Kerja

Terhadap Kinerja Dosen pada

Universitas Musi Rawas”. E - Jurnal

.UM Palembang.

Misbahuddin. (2013). Analisis Data Penelitian Dengan Statistik,.PT. Bumi Aksara. Jakarta.

Mulyasa, E. (2007). Kurikulum Berbasis Kompetensi. PT. Remaja Rosda karya. Bandung.

Nugroho, Agung. (2005). Strategi Jitu Memilih Metode Statistik Penelitian Dengan SPSS. Andi. Jogyakarta.

Peraturan Menteri Pendidikan Nasional Nomor 16 Tahun 2007 tentang Standar Kualifikasi Akademik Kompetensi Guru dan Dosen.

Robbins, Stephen P. (2006.) Perilaka

Organisasi. Terjemahan Molan Benyamin. PT Indeks Kelompok Gramedia. Jakarta.

Robbins, Stephen P. (2013). Manajemen Jilid I. Erlangga. Jakarta.

Respatiningsih, Ida dan Sudirjo, Frans. (2015). Pengaruh Komitmen Organisasi, Motivasi, Kapabilitas dan Kepuasan Kerja terhadap Kinerja Pegawai (Studi Empirik Pada Inspektorat Kabupaten Pemalang. Serat Acitya Jurnal Ilmiah UNTAG Semarang.

Sanusi ,Anwar. (2014). Metodologi Penelitian Bisnis. Salemba Empat. Jakarta.

Simbolon,Sahat. (2017). Pengaruh Kepemimpinan Visioner, Motivasi, dan Kompetensi terhadap Budaya Kerja dan Komitmen Serta Implikasinya pada Kinerja. Kontigensi. Volume 5 No 2 Halaman 87 - 97.

Soegihartono. (2012)(. Pengaruh Kepemimpinan Kepuasaan Kerja Terhadap Kinerja dengan Mediasi Komitmen di PT Kayu Sakti Semarang. Jurnal Mitra Ekonomi dan Manajemen. Vol. 3, No. 1, Hal 123-139. 
Sugiyono. (2010). Metode Penelitian Pendidikan (Pendekatan Kualitatif, Kuantitatif dan R \& D). Alfabeta. Bandung.

Suliyanto. (2006). Metode Riset Bisnis. Andi. Yogyakarta.

Sunyoto, Dadang. (2012). Dasar - Dasar Manajemen Pemasaran Konsep, Strategi, Dan Kasus. CAPS. Yogyakarta.

Thoifah, I'anatut. (2015). Statistika pendidikan dan Metode Penelitian Kuantitatif. Madani. Malang.

Undang-Undang Republik Indonesia Nomor 14 Tahun 2015 tentang Guru dan Dosen.

Wibowo. (2014). Manajemen Kinerja. PT. Grafindo Persada, Jakarta.

Wijayanti, Ratna \& Meftahudin. (2016). Analisa kompetensi terhadap penilaian kinerja dosen (studi kasus dosen UIN Sultan Karim Riau)”. 2016. Kutubhanah, vol 17 no 1 Januari Juni.

Yanuarti, Endah dan W,Suparman, Aris. (2014). Pengaruh Gaya Kepemimpinan, Kepuasan Kerja dan Komitmen Organisasi Terhadap Kinerja Guru Pada SMK Muhammadiyah Kabupaten Gunungkidul. JBTI, vol 5 no 2 Oktober. 